Araştırma Makalesi / Research Article

\title{
Investigation of career stress of tourist guide candidates
}

\author{
Turist rehber adaylarının kariyer streslerinin \\ incelenmesi
}

\author{
Gönderim Tarihi / Received : 06.11.2020 \\ Kabul Tarihi / Accepted : : 30.03.2021 \\ Doi: https://doi.org/10.31795/baunsobed.822505
}

Neslihan KAN SÖNMEZ ${ }^{1}$

\begin{abstract}
The greatest expectation of university students is to find a job in the field they have received education and to have a successful career. Students' stress on whether or not they can achieve these goals after graduation is a significant issue. Determining the perceptions of students related to career stress will contribute to a decrease in the sources of stress. In this study carried out to specify the career stress of tourist guide candidates, the sample group consisted of 210 students enrolled in the Department of Tourism Guidance of Faculty of Tourism in Afyon Kocatepe University. The data collected by a questionnaire were analyzed through statistical techniques such as frequency and percentage distribution, arithmetic mean, standard deviation, $\mathrm{t}$-test and analysis of variance. The obtained data suggested that general career stress levels of tourist guide candidates were below a moderate level. Of the career stress factors, "career ambiguity and lack of information" and "employment pressure" were calculated to have the highest mean values. Additionally, career stress levels of tourist guide candidates differed significantly according to gender, age, grade, and status of working in the tourism sector.
\end{abstract}

Keywords: Tourism, Career stress, Tourist guide candidates, Tourist guiding education.

ÖZ: Üniversite eğitimi alan öğrencilerin en büyük beklentisi eğitim aldıkları alanda çalışabilecekleri bir iş bulabilmek ve başarılı bir kariyer sahibi olabilmektir. Öğrencilerin mezun olduktan sonra bu hedeflere ulaşıp, ulaşamayacaklarına ilişkin yaşadıkları stres önemli bir konudur. Kariyer streslerine yönelik öğrenci algılamalarının belirlenmesi, stres kaynaklarının azaltılmasına yönelik harekete geçilmesine yardımcı olacaktır. Turist rehber adaylarının kariyer streslerinin belirlenmesi amacıyla gerçekleştirilen bu çalışmada, Afyon Kocatepe Üniversitesi Turizm Fakültesi Turizm Rehberliği Bölümü'nde öğrenim gören 210 öğrenci örneklem grubunu oluşturmuştur. Araştırmada, anket tekniğinden yararlanılarak toplanan veriler, frekans ve yüzde dağılımı, aritmetik ortalama, standart sapma, t-testi ve

${ }^{1}$ Dr. Öğr. Üyesi, Harran Üniversitesi/Turizm ve Otel İşletmeciliği Yüksekokulu/Rekreasyon Yönetimi Bölümü/ Rekreasyon Yönetimi Anabilim Dalı, neslihankan@harran.edu.tr,

https://orcid.org/0000-0001-6198-8129 
varyans analizi gibi istatistiksel teknikler ile analiz edilmiştir. Elde edilen bulgulara göre; turizm rehberliği öğrencilerinin genel kariyer stres düzeyleri orta düzeyin altındadır. Kariyer stres faktörleri içerisinden en yüksek ortalama ise "kariyer belirsizliği ve bilgi eksikliği" ile "iş bulma baskısı" faktörleri için hesaplanmıştır. Bununla birlikte turist rehber adaylarının kariyer stres düzeyleri cinsiyet, yaş, sınıf ve turizm sektöründe çalışma durumu değişkenlerine göre anlamlı farklılıklar göstermektedir.

Anahtar Kelimeler: Turizm, Kariyer stresi, Turist rehber adayları, Turist rehberliği eğitimi. 


\section{GENIŞLETILLMIŞ ÖZET}

\section{Literatür taraması}

Üniversite eğitimi alan öğrencilerin en büyük beklentisi eğitim aldıkları alanda çalışabilecekleri bir iş bulabilmek ve başarılı bir kariyer sahibi olabilmektir. Öğrencilerin mezun olduktan sonra bu hedeflere ulaşıp, ulaşamayacaklarına ilişkin yaşadıkları stres önemli bir konudur.

$\mathrm{Bu}$ araştırmanın amacı, Turizm Rehberliği Bölümü'nde öğrenim gören turist rehber adaylarının kariyer streslerinin belirlenmesidir. Turist rehber adaylarının kariyer stres faktörlerinin belirlenmesi gelecekte bu mesleği yapmak isteyip istemediklerinin tespitine ve stres faktörlerinin azaltılmasına yönelik harekete geçilmesine yardımcı olacaktır. Bu nedenle, kariyer stresine neden olan başlıca faktörler hem turizm rehberliği eğitimindeki eksikliklere hem de strese yol açan faktörlere yönelik çözüm yollarını bulmaya 1şık tutacaktır. Yapılan ulusal/uluslararası literatür taramasında turist rehber adaylarının kariyer streslerine yönelik yapılan herhangi bir araştırmaya rastlanmamış olması bu araştırmanın özgün tarafidır.

\section{Yöntem}

Araştırmanın evrenini Afyon Kocatepe Üniversitesi Turizm Fakültesi Turizm Rehberliği Bölümü'nde öğrenim gören öğrenciler oluşturmaktadır. Çalışmada örneklem alınma yoluna gidilmemiş olup "tam sayım” hedeflenmiştir. Bu çerçevede okula devam eden ve uygulamayı kabul eden 221 öğrenci üzerinde anket gerçekleştirilmiş ve eksik-hatalı veriler dikkate alınarak 210 öğrenciden elde edilen anketler değerlendirmeye alınmıştır.

Turizm Rehberliği Bölümü'nde öğrenim gören turist rehber adaylarının kariyer streslerini belirlemek için Nisan, Mayıs 2019 tarihinde iki bölümden oluşan anket uygulanmıştır. Anketin birinci bölümünde turizm rehberliği bölümünde öğrenim gören öğrencilerin bazı bireysel özelliklerine yer verilirken ikinci bölümde ise kariyer stresi ölçeği yer almaktadır. Bu ölçeklerde yer alan maddelerin her biri beşli Likert tipi ölçek olarak hazırlanmıştır.

Araştırmada, verilerin analizinde frekans ve yüzde dağılımı, aritmetik ortalama, standart sapma değerleri hesaplanmış ve değişkenler arasındaki ilişkiler için ise veriler normal dağıldığı için bağımsız örneklemler için t-testi ve tek yönlü varyans analizi kullanılmıştır. Araştırmada ölçeğin geçerliği için faktör analizi uygulanmış olup, güvenirliği için ise Cronbach's Alpha katsayıları hesaplanmıştır. Ölçeğin genel Cronbach's Alpha katsayısı 0,868 bulunurken diğer faktörlere ait katsayılar ise 0,70 değerinin üzerinde hesaplanmıştır. Ayrıca çalışmada öğrencilerin kariyer streslerine göre sınıflandırılması için aşamalı (hiyerarşik) kümeleme yöntemlerinden Ward yöntemi uygulanmıştır (Ward's Hierarchical Cluster Analysis Method). Uzaklık ölçütü olarak ise Ki-kare ölçüsü (Chi-Squared mea- 
sure) kullanılmış ve kümeleme analizine ilişkin dendrogram elde edilmiştir. Söz konusu analizler SPSS 21.0 for Windows paket programı ile analiz edilmiştir.

\section{Bulgular ve tartışma}

Alt boyut veya faktörlere ilişkin aritmetik ortalama değerlerine göre; turist rehber adaylarının kariyer streslerinin beşli tipi derecelemede orta değeri gösteren 3'ün altında olduğu belirlenmiştir. Kariyer stresi alt boyutlarından "iş bulma baskısı" boyutunun kariyer stresini en fazla etkileyen faktör olduğu ve bunu "kariyer belirsizliği ve bilgi eksikliği" boyutunun izlediği görülmektedir. Bu bilgilere "iş bulma baskısı" nın turizm rehberliği bölümünde öğrenim gören öğrencilerin kariyer stresini etkileyen önemli bir faktör olduğu söylenebilir. Ülkemizde son yıllarda açılan bölüm ve üniversite sayılarındaki artış, mezun olan turist rehber adaylarının sayısında artışa neden olmaktadır. Bu durum turist rehber adaylarının özel sektörde meslekleri ile ilgili istihdam sıkıntılarını oluşturmaktadır. Böylelikle iş bulma baskısı yaşanmakta, mesleğinde kariyer yapmak isteyen turist rehber adaylarının önü kapanmakta, kariyer alanlarında yeterli pozisyon olduğu/olmadığı konusunda yaşadıkları endişeler artmakta ve bu durum kariyer stresi yaşamalarına neden olmaktadır. Ayrıca "kariyer belirsizliği/bilgi eksikliği"nin turizm rehber adaylarının kariyer stresini etkileyen önemli bir diğer faktör olduğu söylenebilir. Öğrencilerin kariyer belirsizliği yaşamasında bilgi eksikliği önemli bir faktördür. Turist rehberi adayları, istedikleri kariyerin ne tür nitelikler gerektirdiğini, tercih ettikleri işe yetenekli olup olmadıklarını, istedikleri işe nasıl hazırlanabileceklerini tam olarak bilmiyorlarsa, başarılı bir kariyere ulaşıp ulaşamayacaklarından emin olamazlar. Bu belirsizlik turizm rehberliği öğrencileri üzerinde stres yaratır.

Turizm Rehberliği Bölümü’nde öğrenim gören rehber adaylarının kariyer stres düzeylerinin bazı bireysel özelliklerine göre karşılaştırılmasına yönelik yapılan $t$ testi ve varyans analizi sonuçları, rehberlik öğrencilerinin kariyer stres düzeylerinin cinsiyete, yaşa, sınıfa ve turizm sektöründe çalışma durumuna göre anlamlı bir farklılık gödterdiğini ortaya koymuştur. Buna göre kadın öğrencilerin erkeklere, daha önce turizm sektöründe hiçbir işte çalışmayanların çalışanlara göre kariyer streslerinin daha yüksek olduğu saptanmıştır. Kariyer yaşamı boyunca kadın çalışanların mesleki gelişimleri önünde erkek çalışanlara göre daha fazla engel bulunduğu bilinen bir gerçektir. İlk olarak kadın çalışanların büyük çoğunluğu toplumda kendilerine yüklenen öncelikli roller ve iş hayatının beklentileri arasında yaşadıkları rol çatışmaları (anne-eş rolü ile işkadını rolü arasındaki ikilem) ile iş yaşamına ilişkin isteklerini, kariyer hedeflerini şekillendirmektedir. Ayrıca kadın çalışanlar üst düzey yönetici pozisyonuna yükselmelerinde cam tavan sendromu olarak adlandırılan birtakım engellerle karşılaşırlar. Kadın çalışanların önünde örnek alabileceği rol modelleri de azdır. Bu engellerin var olduğu bir ortamda büyüyen kadın öğrencilerin kariyer streslerinin daha yüksek olması beklenen bir sonuçtur. Nitekim 
turist rehberliği mesleğinde cinsiyet ayrımcılığının olduğu kadın öğrencilerin turist rehberliği mesleğine çalışma koşulları ve işin doğası gereği daha olumsuz yaklaştığı literatürde yapılan araştırmalarla ortaya konulmuştur. Ayrıca bu çalışmada öğrencilerin yaş ve sınıf düzeyi ilerledikçe kariyer stres düzeyinin de buna bağlı olarak arttığı tespit edilmiştir. Bu sonuç öğrencilerin yaz sezonlarında yapmış oldukları staj uygulamaları veya ücretli çalışmalarla, turizm rehberliği mesleği ve turizm işletmelerinin çalışma koşullarını öğrenmeleri ile açıklanabilir. İlk yıllarda kendini her anlamda yeterli gören öğrenci üzerinde stres baskısı hissetmemektedir. Ancak, ilerleyen dönemlerde turizm rehberliği mesleği ve turizm işletmelerinin çalışma koşullarının zor yönleriyle yüzleşen öğrenci, kendini yaptığı işle ilgi yetersiz görmeye başlayacaktır. Bu durum, öğrencinin daha fazla kariyer stresine maruz kalmasına neden olacaktır.

Araştırmada ayrıca öğrenciler, kariyer stres düzeylerine göre Ward kümeleme analizi kullanılarak sınıflandırılmış olup rehber adayları genel olarak 4 kümeye veya gruba ayrılmıştır. Bu gruplar kariyer stres düzeylerinin büyüklüğüne göre yeşil, sarı, turuncu ve kırmızı grup olarak adlandırılmış olup, kırmızı grup en yüksek stres düzeyine sahip grup olurken, en düşük stres düzeyine sahip grup ise yeşil grup olarak nitelenmiştir. Diğer taraftan, öğrencilerin yarıya yakınının kırmızı grubun bir seviye altındaki turuncu grupta yer aldığı saptanmıştır. Buna göre; kırmızı ve turuncu grupta bulunan turist rehber adaylarının diğer gruplara göre kariyer stres düzeyinin daha yüksek olduğu söylenebilir. Rehber adaylarının yarıdan fazlasının kırmızı ve turuncu grupta yer alması ögrencilerin büyük çoğunluğunun kariyer stresi yaşadığını göstermektedir.

\section{Sonuç ve öneriler}

Bu çalışmada elde edilen sonuçlara göre,; üniversite yıllarında turizm rehberliği mesleği hakkında yeterli bilgisi olmayan, mevcut bilgi ve yeteneklerine tam olarak güvenemeyen, kariyer hedefleri açısından bir kararsızlık içinde olan ve iş bulma baskısına maruz kalan rehber adaylarının büyük çoğunluğunun strese maruz kaldığı görülmektedir. Yaşanılan bu stresi tamamen ortadan kaldırmak mümkün olmasa bile azaltmak için ilk olarak "kariyer planlama" veya "kariyer gelişimi" dersinin müfredata konulması önerilebilir. Bununla birlikte turizm rehberliği mesleğine ilişkin teorik bilgilerin pratik uygulamalarla, sektörel örneklerle desteklendiği derslerin müfredata konularak alanında uzman akademisyenler tarafından yürütülmesi önerilebilir. Bu derslerde iş hayatında turist rehber adaylarının karşılaşabilecekleri stres faktörleri açık ve net bir şekilde uygulamalı olarak aktarılabilir. Özellikle kokartlı turist rehberi olan akademisyenlerin ve turizm rehberliği bölümünde görev yapan diğer tüm akademisyenlerin vereceği danışmanlık hizmetlerinden yararlanmaları sağlanabilir. Rehber adaylarının üzerlerine düşen sorumlulukları üstlenmeleri ve kendilerini turizm rehberliği mesleğine uygun olarak yetiştirmeleri için sorumluluk sahibi bireyler olmalarına destek verilebilir. 


\section{Introduction}

Tourism is one of the fastest growing and economic income providing sectors. Tourists constitute the basis of tourism sector. Whether a tourist participates in national tourism or international tourism, s/he is aware that $s /$ he will be in a different environment other than his/her own circle and s/he will need help in many issues in this unfamiliar environment. All tourists may indeed prefer static guides when they obtain information on any place they will go to. However, most of tourists prefer to obtain information from tourist guides (Değirmencioğlu \& Ahipaşaoğlu, 2003; Köroğlu, 2013). As a result of this intensive demand regarding the benefit from the knowledge of individuals, who have chosen guidance as a profession, tourist guides are today essential employees of the tourism industry.

While the lexical meaning of guide refers to a person or object which guides someone and helps him/her find the truth by guiding (Türk Dil Kurumu, 2020), there are many definitions related to tourist guide in the literature. Of these definitions, it can be argued that the one made by the World Federation of Tourist Guide Associations is generally accepted and still valid. According to WFTGA, a guide is someone guiding people who participate in a tour in their desired language and generally having a license granted by an authorized body and describing the cultural and natural heritage of a region verbally (WFTGA, 2020). Another definition has been made by Pond (1993). Pond (1993) asserts that a guide is a leader who can take responsibility, a trainer who allows tourists to understand the regions they visit, a hospitable messenger who introduces a destination in a way that encourage visitors to come back, a host who provides a comfortable environment for visitors and a facilitator who knows when and how to perform these four roles (Ap \& Wong, 2001). Black and Weiler (2005) have examined the studies conducted related to the tourist guiding between the years of 1979-2001. In 12 of these studies, they have found out ten following roles expected from the guides: interpreter/trainer, informant, leader, protection values motivator/role model, social role/catalyst, cultural mediator/mediator, traveller/guardian, tour and group manager/organizer, public relations practitioner/company representative and facilitator of access to non-public spaces. However, it has been stated in many studies that the number of these roles attributed to guides and their relative significance changed in accordance with tour type, type of group, their needs and interests, expectations of employers and industry from guides (Weiler \& Black, 2015).

The tourist guides are considered to be an important part of tourism product and experience and sometimes a key player in the tourism industry either they are employed by tour operators, travel agencies, theme parks, resort hotels, protection area administrations, attraction centres or they are self-employed 
(Weiler \& Black, 2015). Therefore, it is argued that tourist guides should have unique knowledge and ability set, and should be professional in finding solutions to various difficulties (Cheng et al., 2016). In order to train a qualified tourist guide with these qualifications, a quality education should be provided (Hacıoğlu, 2008).

In Turkey, tourist guide education is given by formal education, informal education and distance education (Kardaş, 2020). The formal training has three different levels: associate degree, undergraduate and graduate (Master's degree). In the 2019-2020 academic year, the tourist guiding education is provided with an enrolment rate around $95 \%$ at the level of associate degree in 25 vocational schools at 21 universities. While the tourist guiding education is provided with an enrolment rate around $99 \%$ at the level of undergraduate in 38 colleges and faculties at 36 universities, there are 15 universities offering the tourist guiding education at the level of master in 24 programs. The distance tourist guiding education program is provided only by two vocation schools at the level of associate degree (YÖK Atlas, 2019). Whereas informal tourist guiding education was given at courses offered by the Ministry of Culture and Tourism until 2012, such education is now carried out with the certificate programs organized by the associations in the region and language, which is needed, with the approval granted by the Ministry of Culture and Tourism following the entry into force of Tourist Guidance Professional Law No. 6326 in 2012 (Official Gazette, 2014).

All guide candidates graduated from the aforementioned levels have the same rights with the diplomas awarded and can serve as a tourist guide (Temizkan, 2010). Tourist guiding occupation is attractive for and demanded by many people as it requires people to become active in social environments and allows people to entertain while earning money. Although it is considered an occupation in which people entertain more than work and also earn money, the tourist guiding occupation has special problems and characteristics. Some of these may be ranked as follows: long and unspecified working hours, being a seasonal job, high unemployment risk factor, being dependent on external factors (natural disaster, political crisis, etc.), necessity to constantly renew himself/herself, no or late retirement, being based on physical power, being an interdisciplinary occupation, problems related to private and family life caused by long travels (Ahipaşaoğlu, 2007; Güzel, 2007; Çınar, 2018). When considering the above-mentioned information about the special problems and characteristics of the tourist guiding occupation, the roles and duties undertaken by tourist guides, and the increase in demand for tourism guiding education through formal, informal and distance education, it is clear that there are many sources to make the tourist guide candidates stressful about their career. These sources of stress make it difficult for tourist guide candidates to plan a proper career. It is important for the candidates to cope with such 
sources of stress so that they can fulfill their jobs as a successful tourist guide (Dumanlı \& Köroğlu, 2018).

The term of stress was firstly mentioned in the literature with the leading studies of Selye, who is a famous medical specialist in psychological stress in the 1950s and it has been used in social sciences research ever since (Areekkuzhiyil, 2014). Robbins (2001) argues that stress is a dynamic condition in which individual faces an opportunity, limitation or demand related to what $s /$ he desires and in which the result is perceived as both uncertain and important. It is likely for an individual to encounter many different sources of stress throughout life. Stress is a result of the perception that an individual does not have any resource to overcome such a case (Lazarus, 1993). Stress emerges when an individual faces a circumstance that $\mathrm{s} /$ he considers to be depressive and challenging (Agolla \& Ongori, 2009).

When stress reaches an unacceptable levels, it results in individual consequences, such as reduced productivity, reduced initiative, stiffness of interest and thought, loss of responsibility, and physical health impairment as a result of the deterioration of the psychological health of the individual (Greenberg \& Baron, 1995; Bhagat et al., 2010). It is not likely to remove such a stress affecting both the psychological and physiological state of an individual. For this reason, people should learn how to cope with stress and to keep it under control in order to be protected from the negative effects of it. The most important way to control stress is to identify its sources. Stress cannot be controlled unless its sources are specified (Gbadamosi \& Ross, 2012).

Stress sources can be examined in two groups as internal and external environmental stress sources. In internal environmental sources, family lives of individuals and factors related to their inner world are effective. The internal expectations of individuals, such as respect, love, trust, justice, and honesty are effective on both internal and external stress factors. Stress factors which are developed depending on the external environment are caused by the effects on individuals due to changes in technological, political, socio-cultural, economic and life standards (Gümüştekin \& Gültekin, 2009; Turpcu \& Akyurt, 2018). In general, students face many internal and external environment stress sources during their university years. Some of these stress sources are academic issues, financial concerns, social relationships and goals related to career. However, students reported the career-related issues at the highest rate among all these stress sources (Jang, 2000; Kim, 2003; Özden \& Sertel Berk, 2017).

The lexical meaning of career is a degree, success and specialization achieved in an occupation over time and by working (Türk Dil Kurumu, 2020). Based on this definition, it can be asserted that career is generally considered as a promotion, obtaining a certain status, progress and having a preferred profession (Sabuncuoğlu, 2005). 
According to another definition, career refers to a promotion in the preferred business life and thus earning more money, undertaking more responsibility, obtaining more status, power and prestige (Can, Akgün \& Kavuncubaş1, 1998; Mavisu 2010). The common point of the definitions of the term of career, which can be defined in different perspectives, is its association with the degree of success. For this reason, it is considered as a term desired by people in business life (Sav, 2008).

Individuals face many stress factors in their career goals and planning. Students have stress especially during their education regarding their career expectations and must cope with stress in order to achieve the career they desire (Turpcu \& Akyurt, 2018).

As of their university education, it is a must for students to identify their career goals and to participate in working life in accordance with a career plan. However, it has been found out that many university students have some difficulties in making a career plan, their psychological distress levels are higher than other members of the general population and they have a low level of psychological well-being (Fouad et al., 2006). Similarly, it has been identified that the university students with a career decision were significantly less depressive than the ones without any career plan. In the study carried out by Rottinghaus, Jenkins and Jantzer (2009) on 338 university students, the most important problems faced by students in their career planning were ranked as not considering themselves qualified in the decision-making process, not recognizing their personal characteristics and abilities well, and having difficulties in determining their goals related to life (Özden \& Sertel Berk, 2017). In another study conducted by Iş1k (2010) on 321 university students, the problems of students in their career process and sources of stress were ranked as follows: considering himself/herself unqualified in taking personal decisions, not recognizing himself/herself sufficiently, having difficulties in specifying proper goals. Employment pressure, career ambiguity and lack of information were found to have an effect on the career stress in the research carried out by Turpcu and Akyurt (2018) on 223 undergraduate students receiving tourism education and in the investigation conducted by Yilmaz (2019) on 537 pre-service teachers.

Based on the information provided above, the purpose of this study was to determine the career stress of tourist guide candidates enrolled in the department of Tourism Guiding. Identifying the career stress factors of tourist guide candidates would contribute to identification of whether they want to perform this job and reduce their stress factors. In this regard, the primary factors which cause career stress provide an insight into finding solutions for both the deficiencies in tourism guiding education and the factors causing stress. 
This study is original due to the fact that no study regarding the career stress of tourist guide candidates can be found in national/international literature.

\section{Method}

A questionnaire was administered to collect the data of this study. This questionnaire was applied on the months of April and May of 2019. The questionnaire consists of two sections. While some individual characteristics (gender, age, grade and status of working in the tourism sector) of the students receiving education in tourism guiding departments were included in the first section, the second section consisted of the scale developed by Choi and associates (2011) to determine career stress of students. The scale was adapted into the Turkish language by Özden and Sertel Berk (2017) and it consisted of 20 items including three dimensions (career ambiguity and lack of information, external conflict and employment pressure). The items were organized in fivepoint Likert type and rated as follows: " " 1 = Strongly Disagree”, " 2 = Slightly Agree", "3 = Moderately Agree”, "4 = Agree”, "5 = Strongly Agree”.

The population of the study was all students receiving education in Afyon Kocatepe University, Faculty of Tourism, Department of Tourism Guiding. In this study, no sampling was taken and "complete inventory" was aimed at. In this respect, the questionnaire was administered to 221 students attending courses and becoming voluntary to fill in questionnaire, and the questionnaire papers obtained from 210 students were assessed by considering missingwrong data.

In the study, frequency and percentage distribution, arithmetic mean, standard deviation values were calculated through the analysis of the data. In the interpretation of Likert intervals, the following values were used: 1.00-1.80 range very low, 1.81-2.60 range low, 2.61-3.40 range medium, 3.41-4.20 range high, 4.21-5 range very high (Ural \& Kılıç, 2005; Bayat, 2014; Kaplanoğlu, 2014). Regarding the relationships between variables, t-test and one-way analysis of variance were utilized for independent samples as the data were normally distributed. Besides, factor analysis was carried out for the validity of the scale, and Cronbach's Alpha coefficients were calculated for its reliability. In order to classify the students with regard to their career stress (by using 20 items of the career stress scale), Ward's method from hierarchical cluster analysis methods was used. Chi-square measure was utilized as the distance criterion and the dendrogram related to clustering analysis were obtained. These analyses were performed using SPSS 21.0 for Windows package program. 


\section{Results}

The distribution of the subjects according to some demographic characteristics is presented in Table 1 . In this respect, while $46,2 \%$ of the subjects were female, $53,8 \%$ of them were male. $17,1 \%$ of the students were below $20,46,2 \%$ of them were at $21-22$ and $36,7 \%$ of them were at 23 and above. On the other hand, $17,6 \%$ of them were enrolled in the 1 st grade, $27,1 \%$ of them were at the 2 nd grade, $19,5 \%$ of them were at the 3 rd grade and $35,7 \%$ of them were enrolled in the 4 th and further grades (suspending students). Whereas 59,5\% of the students stated that they were working in the tourism sector, 40,5\% of them expressed that they did not work.

Table 1: The distribution of the subjects according to some individual characteristics

\begin{tabular}{llcc}
\hline Variable & Group & Number (f) & Percent (\%) \\
\hline \multirow{2}{*}{ Gender } & Female & 97 & 46,2 \\
& Male & 113 & 53,8 \\
\hline \multirow{3}{*}{ Age } & 20 and below & 36 & 17,1 \\
& $21-22$ & 97 & 46,2 \\
& 23 and above & 77 & 36,7 \\
\hline \multirow{3}{*}{ Grade } & 1 & 37 & 17,6 \\
& 2 & 57 & 27,1 \\
\multirow{2}{*}{ Working status in the tourism sector } & Worked & 41 & 19,5 \\
\cline { 2 - 4 } & Did not work & 75 & 35,7 \\
\hline & Total & $\mathbf{2 1 0}$ & $\mathbf{1 2 5}$ \\
\hline
\end{tabular}

In Table 2, the factor analysis, Cronbach's Alpha coefficients utilized for the construct validity of the career stress scale and some statistics regarding the scale are provided. Bartlett's test and KMO values revealed that the sample size was sufficient for factor analysis to be performed (KMO $=0.893$; Bartlett's Test: $\chi 2=3388.1 ; \mathrm{P}<0.001)$. When examining the results of the factor analysis, it is seen that the career stress scale had 3 factors, explaining 68,082\% of the total variance. While the general Cronbach's Alpha coefficient of the scale was found to be 0,868 , the coefficients of other factors were calculated to be above 0,70 . When examining the arithmetic mean values of the sub-dimension or factors, it is seen that career stress is generally below $3(\bar{X}=2,44)$, indicating the moderate value in the five-point rating. The mean value of the dimension of "employment pressure" $(\bar{X}=2,85)$ from the career stress dimensions was identified to be higher than other dimensions. 
Table 2: Validity and reliability results of the career stress scale and some descriptive statistics

\begin{tabular}{|c|c|c|c|c|c|c|}
\hline Factors & 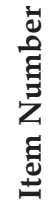 & 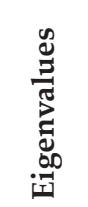 & 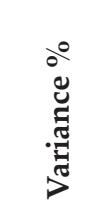 & 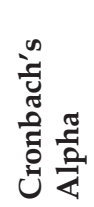 & $\overline{\mathrm{X}}$ & SS \\
\hline F1: Career Ambiguity and Lack of Information & 10 & 5,540 & 27,699 & 0,879 & 2,31 & 0,91 \\
\hline F2: Employment Pressure & 6 & 4,470 & 22,352 & 0,832 & 2,85 & 0,86 \\
\hline F3: External Conflict & 4 & 3,606 & 18,031 & 0,816 & 2,13 & 0,99 \\
\hline General Career Stress & 20 & - & 68,082 & 0,868 & 2,44 & 0,83 \\
\hline
\end{tabular}

Kaiser-Meyer-Olkin $(K M O)=0,893 ;$ Bartlett's Testi: $\chi 2=3388,1 ; P<0,001$

Table 3: Descriptive statistics on the items of the career stress inventory

\begin{tabular}{|c|c|c|c|c|c|c|c|}
\hline \multirow{3}{*}{ DIMENSIONS / ITEMS } & \multicolumn{5}{|c|}{ Respond Level } & \multirow{3}{*}{$\bar{X}$} & \multirow{3}{*}{ ss } \\
\hline & $\begin{array}{l}\text { ñ } \\
\text { O } \\
\mathbf{Z}\end{array}$ & 3 & 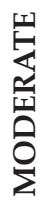 & $\underset{U}{\mathbb{U}}$ & 罗 & & \\
\hline & $\%$ & $\%$ & $\%$ & $\%$ & $\%$ & & \\
\hline
\end{tabular}

\section{External Conflict}

1. I have conflict with my family because my family urges me to have a guaranteed job but ignores what I attach importance

2. Although I am satisfied with my career plan, I am concerned that it will not meet the expectations of people who are close to me

3. Negative opinions of others about my career choice preoccupy my mind

4. I have conflict with my family because what they want me to do and what I want to do are different

\section{Employment Pressure}

5. I am concerned about the fact that there are sufficient position in my career plan

$\begin{array}{lllllll}16,7 & 23,8 & 40,5 & 16,7 & 2,4 & 2,64 & 1,02\end{array}$

6. I am concerned about failing in the job examination in the first time

$\begin{array}{lllllll}7,6 & 20,0 & 41,4 & 17,1 & 13,8 & 3,10 & 1,11\end{array}$

7. I am concerned about the fact that the job I want will not provide a guarantee income for me $\begin{array}{lllllll}41,0 & 18,6 & 29,0 & 5,7 & 5,7 & 2,17 & 1,19\end{array}$

$\begin{array}{lllllll}40,5 & 19,5 & 28,1 & 9,0 & 2,9 & 2,14 & 1,14\end{array}$

$36,0 \quad 21,9 \quad 21,9 \quad 21,9 \quad 3,8 \quad 2,21 \quad 1,20$

$\begin{array}{lllllll}43,8 & 28,6 & 14,8 & 8,6 & 4,3 & 2,01 & 1,15\end{array}$
$23,3 \quad 35,2 \quad 26,7 \quad 11,9 \quad 2,9 \quad 2,36 \quad 1,05$ 
Table 3 (More): Descriptive statistics on the items of the career stress inventory

\begin{tabular}{|c|c|c|c|c|c|c|c|}
\hline \multirow{3}{*}{ DIMENSIONS / ITEMS } & \multicolumn{5}{|c|}{ Respond Level } & \multirow{3}{*}{$\bar{X}$} & \multirow{3}{*}{ SS } \\
\hline & $\begin{array}{l}\text { 崩 } \\
\text { O } \\
\text { Z }\end{array}$ & 3 & 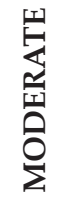 & 胥 & 哥 & & \\
\hline & $\%$ & $\%$ & $\%$ & $\%$ & $\%$ & & \\
\hline $\begin{array}{l}\text { 8. I feel myself stressed because it is difficult to } \\
\text { study lesson as well as to prepare for a job }\end{array}$ & 11,4 & 23,3 & 29,0 & 21,4 & 14,8 & 3,05 & 1,22 \\
\hline $\begin{array}{l}\text { 9. I feel myself stressed because there are } \\
\text { many things to do to find a job }\end{array}$ & 10,0 & 21,4 & 25,7 & 29,5 & 13,3 & 3,15 & 1,19 \\
\hline $\begin{array}{l}\text { 10. I am concerned that I cannot not have the } \\
\text { job I want }\end{array}$ & 11,4 & 31,0 & 26,2 & 23,3 & 8,1 & 2,86 & 1,14 \\
\hline
\end{tabular}

\section{Career Ambiguity and Lack of Information}

11. I feel myself blocked since I do not know what is necessary for my career

$41,4 \quad 18,1 \quad 26,7 \quad 9,0 \quad 4,8 \quad 2,18 \quad 1,20$

12. I am concerned about having insufficient information regarding the job I want

$\begin{array}{lllllll}17,6 & 31,4 & 24,3 & 24,3 & 2,4 & 2,62 & 1,11\end{array}$

13. I feel myself blocked since I do not know what to do in the future

$27,6 \quad 24,8 \quad 22,4 \quad 17,6 \quad 7,6 \quad 2,53 \quad 1,27$

14. I feel myself blocked since I do not know what kind of qualifications the career I desire requires

15. I feel myself blocked since I do not know exactly how I can prepare for the job I want

16. I feel myself blocked since there are few people helping me in preparing for my career

17. I am concerned since I do not have an exact decision on the career I want

$28,1 \quad 27,6 \quad 33,3 \quad 8,6 \quad 2,4 \quad 2,30 \quad 1,04$

$27,6 \quad 30,0 \quad 25,2 \quad 14,8 \quad 2,4 \quad 2,34 \quad 1,11$

$23,3 \quad 36,2 \quad 27,6 \quad 8,1 \quad 4,8 \quad 2,35 \quad 1,07$

$31,0 \quad 27,1 \quad 27,6 \quad 11,4 \quad 2,9 \quad 2,28 \quad 1,11$

18. I feel myself blocked because I doubt that what I'm planning for my future is what I really want

19. I have concerns on whether the job I have preferred and my abilities are complied with

20. I am concerned about the fact that I don't know what my skills are

$32,4 \quad 23,3 \quad 30,5 \quad 8,6 \quad 5,2 \quad 2,31 \quad 1,16$

$31,0 \quad 37,1 \quad 14,8 \quad 12,9 \quad 4,3 \quad 2,22 \quad 1,15$

$38,1 \quad 29,0 \quad 27,1 \quad 2,4 \quad 3,3 \quad 2,04 \quad 1,03$

The descriptive statistics regarding the items of the career stress scale are given in Table 3. When the results are examined, it was identified that the guide candidates studying in the Tourism Guiding Department did not have much "external conflict" and did not have any conflict with their families on 
their careers. Regarding the dimension of "employment pressure", it was determined respectively that the mean values of the following items were found to be higher: "I feel myself stressed because there are many things to do to find a job" $(X=3,15)$, "I am concerned about failing in the job examination in the first time" $(\bar{X}=3,10)$ and "I feel stressed because it is difficult to study lesson as well as to prepare for a job" ( $\bar{X}=3,05)$. In the dimension of "career ambiguity and lack of information", it was identified that the following items had higher mean values: "I am concerned about having insufficient information regarding the job I want" $(\bar{X}=2,62)$ and "I feel blocked since I do not know what to do in the future" ( $\bar{X}=2,53)$.

The results of $t$ test and analysis of variance for the comparison of career stress levels of guide candidates enrolled in the Tourism Guiding Department in terms of some individual characteristics are provided in Table 4 . When the results of the analysis are examined, it was found that the career stress levels of guide candidates showed significant differences according to gender, age, class, working status in the tourism sector $(\mathrm{P}<0,05)$. When mean values of the groups were considered, it was revealed that female students $(\bar{X}=2,61)$ had higher career stress than male students $(\bar{X}=2,29)$. On the other hand, it was seen that as age and grade were higher, career stress level increased, too. It was also found that the career stress of those not working in the tourism sector before $(\bar{X}=2,58)$ was higher than those employed in the tourism sector $(\bar{X}=2,31)$.

Table 4: Comparison of career stress according to some individual characteristics of the subjects

\begin{tabular}{|c|c|c|c|c|}
\hline Gender & Group & $\bar{X}$ & SS & $\mathbf{P}$ \\
\hline \multirow{2}{*}{ Gender } & Female & 2,61 & 0,86 & \multirow{2}{*}{$0,005^{* *}$} \\
\hline & Male & 2,29 & 0,78 & \\
\hline \multirow{3}{*}{ Age } & 20 and below & $2,09 \mathrm{a}$ & 0,62 & \multirow{3}{*}{$0,023^{*}$} \\
\hline & $21-22$ & $2,30 \mathrm{~b}$ & 0,81 & \\
\hline & 23 and above & $2,62 \mathrm{c}$ & 0,91 & \\
\hline \multirow{4}{*}{ Grade } & 1 & $2,10 \mathrm{a}$ & 0,64 & \multirow{4}{*}{$0,001^{* *}$} \\
\hline & 2 & $2,25 \mathrm{~b}$ & 0,74 & \\
\hline & 3 & $2,52 \mathrm{c}$ & 0,92 & \\
\hline & 4 and + & $2,70 \mathrm{~d}$ & 0,84 & \\
\hline \multirow{2}{*}{ Working status in the tourism sector } & Worked & 2,31 & 0,74 & \multirow{2}{*}{$0,042^{*}$} \\
\hline & Not worked & 2,58 & 0,93 & \\
\hline
\end{tabular}

${ }^{*} P<0,05 ;{ }^{* *} P<0,01 \quad a, b, c, d$ : there are significant differences between groups with different letters.

In the research, Ward's clustering analysis was performed to classify the guide candidates according to career stress levels, and the dendogram in Figure 1 was obtained. When the dendogram graphic is examined, it was observed that 
the students were classified into two basic clusters over 15 distance values, then each of these two clusters were divided into two over 12 distance values (in the reference region shown with the red line) and a total of four clusters were formed. These clusters were compared with the variance analysis, and related results are shown in Table 5 . At the end of the variance analysis, significant differences were identified among all groups regarding each dimension and general career stress. When arithmetic mean values were examined, it was seen that the 1 st group, constituting $13,3 \%$ of all guide candidates, was very relaxed regarding all dimensions and Arithmetic mean values, and they had quite low career stress level $(\bar{X}=1,62)$, therefore, this group was named 'green group'. It was revealed that all dimension and general career stress levels of the 2 nd group, constituting $30,2 \%$ of all guide candidates, were higher than the 1st group although these values were low $(\bar{X}=1,98)$, thus, this group was called 'yellow group'. It was determined that the all dimension and general career stress levels of the 3rd group, constituting $44,1 \%$ of all students, were higher than other two groups ( $\bar{X}=2,73)$, therefore, this group was named 'orange group'. The group with the highest stress level regarding three dimensions and the general career stress was the 4 th group, constituting $12,4 \%$ of guide candidates $(\bar{X}=3,38)$, thus, this group was called 'red group'.

Figure 1: Dendrogram graphic obtained by ward's method

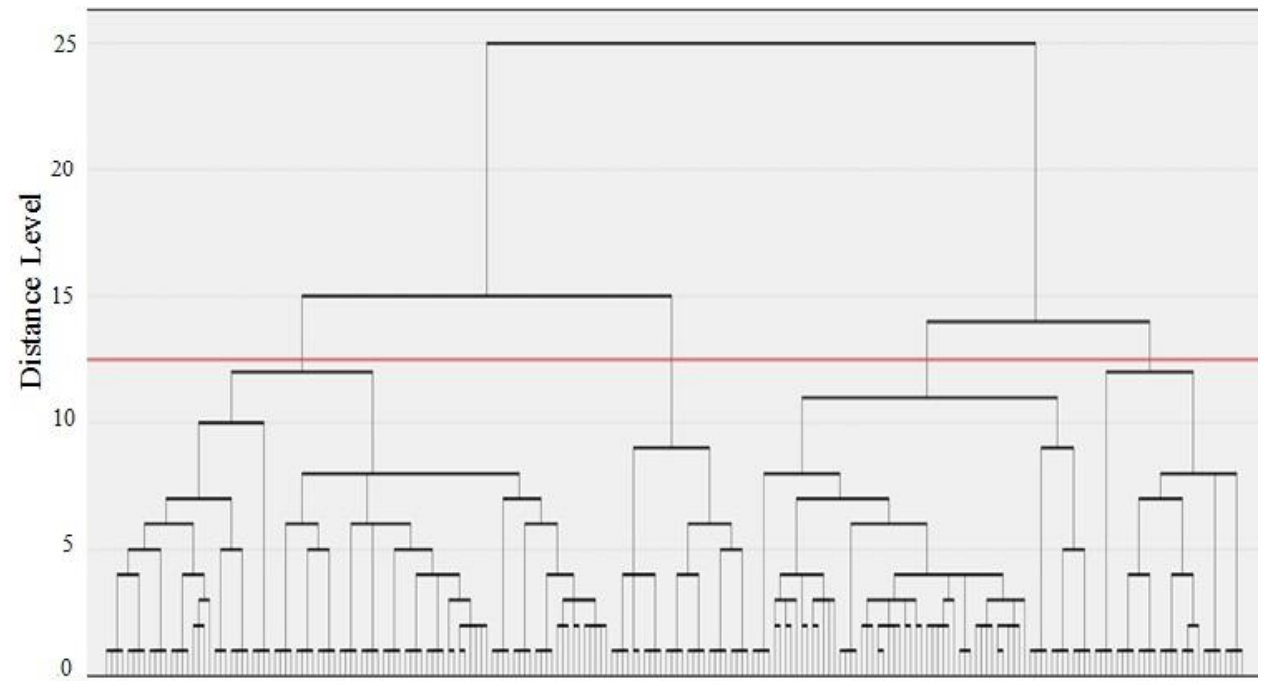


Table 5: Comparison of career stress according to the groups obtained from cluster analysis

\begin{tabular}{|c|c|c|c|c|c|c|c|c|c|c|}
\hline \multirow[t]{2}{*}{ Groups } & \multirow[t]{2}{*}{$\mathbf{n}$} & \multirow[t]{2}{*}{$\%$} & \multicolumn{2}{|c|}{$\begin{array}{l}\text { External } \\
\text { Conflict }\end{array}$} & \multicolumn{2}{|c|}{$\begin{array}{c}\text { Employment } \\
\text { Pressure }\end{array}$} & \multicolumn{2}{|c|}{$\begin{array}{c}\text { Career } \\
\text { Ambiguity } \\
\text { and Lack of } \\
\text { Information }\end{array}$} & \multicolumn{2}{|c|}{$\begin{array}{c}\text { General Career } \\
\text { Stress }\end{array}$} \\
\hline & & & $\bar{X}$ & SD & $\bar{X}$ & SD & $\bar{X}$ & SD & $\bar{X}$ & SD \\
\hline 1: Green & 28 & 13,3 & $1,42^{\mathrm{a}}$ & 0,61 & $2,27^{a}$ & 0,86 & $1,38^{\mathrm{a}}$ & 0,32 & $1,62^{a}$ & 0,45 \\
\hline 2: Yellow & 63 & 30,0 & $1,69^{b}$ & 0,50 & $2,64^{\mathrm{b}}$ & 0,76 & $1,70^{\mathrm{b}}$ & 0,50 & $1,98^{\mathrm{b}}$ & 0,48 \\
\hline 3: Orange & 93 & 44,3 & $2,25^{c}$ & 0,84 & $2,90^{c}$ & 0,79 & $2,79^{c}$ & 0,76 & $2,73^{c}$ & 0,73 \\
\hline \multirow[t]{2}{*}{ 4: Red } & 26 & 12,4 & $3,69^{d}$ & 0,88 & $3,67^{d}$ & 0,63 & $3,08^{d}$ & 0,80 & $3,38^{d}$ & 0,74 \\
\hline & & $\mathrm{P}=$ & \multicolumn{2}{|c|}{$0,000^{* *}$} & \multicolumn{2}{|c|}{$0,000^{* *}$} & \multicolumn{2}{|c|}{$0,000^{* *}$} & \multicolumn{2}{|c|}{$0,000^{* *}$} \\
\hline
\end{tabular}

${ }^{* *} P<0,01$ a,b,c,d: there are significant differences between groups with different letters.

\section{Discussion and conclusion}

210 students receiving education at Afyon Kocatepe University, Faculty of Tourism, Department of Tourism Guiding participated in this study which was carried out to determine the career stress of tourist guide candidates. It was concluded at the end of this study that the general career stress of tourist guide candidates was found to be below moderate level. Some results in the literature confirm this finding. In the study carried out by Çınar (2018) on 537 students from the department of tourism guiding and in the research conducted by Bozyiğit and Gökbaraz (2020) with the participation of 280 students enrolled in the faculty of sport sciences and in the investigation carried out by Çetinkaya (2019) with 527 students studying in the physical education and sports academy, it was reported that career stress of the students was below moderate level as founded in this study. The study performed by Turpcu and Akyurt (2018) on 223 undergraduate students receiving tourism education and the research carried out by Yllmaz (2019) on 239 pre-service teachers revealed that the career stress of students was at moderate level.

It was also determined in this study that the dimension of 'employment pressure' was the factor affecting career stress the most, which was followed by the dimension of 'career ambiguity and lack of information'. In a similar vein, Turpcu and Akyurt (2018) asserted that the greatest concern of the undergraduate students receiving tourism education was the employment pressure, which was followed by the career ambiguity, the second most important stress source. It was also reported in the study conducted by Yilmaz (2019) that the dimensions of 'employment pressure' and 'career ambiguity/ lack of information' affected the career stress. Upon these, it can be argued that the results obtained in this study are in the parallel of the relevant literature 
and that the 'employment pressure' is an important factor affecting the career stress of students enrolled in the tourism guiding department. The increase in the number of departments and universities opened in our country in recent years resulted in an increase in the number of tourist guide candidate graduated. This causes employment problems of the tourist guide candidates in the private sector related to their occupation. Thus, employment pressure occurs and the tourist guide candidates wanting to have a successful career are prevented, their concerns on whether there are sufficient position in the career field increase and this causes them to have career stress. It was also revealed in this study that the tourist guide candidates feel stressed and pressured due to feeling of failure especially in recruitment process, the abundance of what needs to be done to find a job, their career goals and intensity at school. When the tourism guiding candidates do not trust in their characteristics, abilities, qualifications, they feel themselves incapable during recruitment process, and they fell themselves unsuccessful. Students experience stresses such as failing to satisfy, not fulfilling their occupation properly and being criticized, and feel themselves under pressure. When students have professional and personal development, their self-confidence will increase. This confidence will reduce the stress and pressure students have, thus, they will not feel unsuccessful in the recruitment process. At the same time, they will be more successful in fulfilling their responsibilities as students and in doing what is necessary to find a job.

According to the research results, it can be argued that the 'carrier ambiguity/ lack of information' is another important factor that affects the career stress of the tourism guiding candidates. Lack of information is a significant factor in students' having carrier ambiguity (Lease, 2004). If tourist guide candidates do not know exactly what kind of qualifications the carrier they want requires, whether they are skilled for the job they preferred, how they can be prepared for the job they want, they cannot be certain whether they will achieve a successful career. This ambiguity brings along stress for the tourist guide candidates. In order to decrease this stress, vocational guidance and counseling practices provided by universities should focus on embodying the information about the tourism guiding occupation and the working environment as well as improving students' career decision-making skills.

Furthermore, it has been also found that the tourist guiding students do not have many conflicts with their families regarding their career. Based on this result achieved, it can be suggested that the wishes of tourist guide students and their families are compatible, their families do not create pressure on them for finding a different job, and the desires of the guide candidates are paid attention and supported by their families. The support of family leads to a positive effect on students' career development processes (Turner \& Lapan, 2002). Families affect the occupational development process of students significantly not 
only with their supportive, authoritarian, or democratic attitudes in family relationships but also with their attitudes and behaviours supporting students' occupational development (Özdel, 2009; Şeker \& Kaya, 2018). Previous studies (Bryant, Zvonkovic \& Reynolds, 2006; Keller \& Whiston, 2008) also show that families play an important role in the career development process of students in many respects.

In this study, the career stress levels of the guiding students were compared with regard to gender, age, grade and working status in the tourism sector, and significant differences were determined. Accordingly, it was identified that the career stress of female students was higher compared to male students, which also applied for those not working in the tourism sector before compared to those worked previously in the tourism sector. It is a fact that there are more obstacles for female employees compared to male employees in the occupational development process (Tükeltürk \& Perçin, 2008; Doğan \& Bozgeyikli, 2014). Initially, most of the female employees shape their occupation related desires and career goals according to the roles attributed to them in the society and role conflicts they experience between the expectations of business life (dilemma between the role of mother-wife and the role of businesswoman) (Crampton \& Mishra, 1999). Moreover, female employees encounter a number of obstacles called glass ceiling syndrome in their promotion to the position of senior manager. There are few role models for female employees (Örücü, Kılıç \& Kilıç, 2007). It is an expected result that female students growing up in an environment with these obstacles have greater career stress. It was reported in the previous studies that gender apartheid is seen in the tourism guiding occupation (Yılmaz \& Köroğlu, 2012) and female students approach the tourism guiding occupation more negatively due to its nature and working conditions (Yılmaz \& Köroğlu, 2012). In this regard, in order to break taboos regarding the gender apartheid and to remove negative approaches of female students to this occupation, it may be suggested to organize conferences and panels at universities. Interviews may be conducted with female tourist guides in certain periods of each academic year in order to provide role models for female students. Courses such as gender roles can be included in the curriculum of tourism guidance (Çınar, 2018). Another result with a significant difference is the fact that the career stress of those not working in the tourism sector before was higher compared to those worked previously in the tourism sector. Upon this result, it can be claimed that the primary reason making students stressed is related to their attempt to know enterprises in the tourism sector and their wishes to experience the tourist guiding occupation. The ambiguity experienced by the students unfamiliar with the tourism sector and the tourist guiding occupation make them stressed regarding their career expectations (Turpcu \& Akyurt, 2018). Besides, as these students try to prove themselves, aware of 
the opportunity to progress if they prove themselves, and most importantly, knowing that they must work hard for this expose them to more stress related to their career (Özmutaf, 2006). In the study carried out by Turpcu and Akyurt (2018) on the undergraduate students receiving tourism education, it was also determined that the career stress of students not working in the tourism sector before was higher compared to those worked previously in the tourism sector. However, there was not a significant difference between gender and career stress. Çınar (2018) suggested that the female students studying in the tourism guiding had more occupational concern compared to the male students.

It was also achieved in this study that as the age and grade level of the students increased, their career stress level increased accordingly. This conclusion may be explained by the fact that the students are getting familiar with the tourism guiding occupation and working conditions of tourism enterprises due to practical training they fulfill in summers or paid employment. A student considering him/her qualified in all respects in initial years does not feel any stress or pressure. However, the student facing the difficult aspects of the tourism guiding occupation and the working conditions of the tourism enterprises will begin to consider himself/herself unqualified. This will cause more career stress for them. In a similar vein to this research, Çınar (2018) argued that the first year guide candidates had less occupational concern than the ones in higher grades. It was reported by Tolga, Korkmaz and Atay (2015) that the first year tourist guide candidates approached positively to this occupation compared to last year tourist guide candidates. In the study conducted by Weng, Chiang and Lee (2014), it was revealed that the anxiety level of the students performing practical training in the tourism sector increased relatively following the practical training.

In this study, the students were also classified according to their career stress levels using the Ward's clustering analysis and guidance candidates were generally divided into 4 clusters or groups. These groups were named after green, yellow, orange and red groups in accordance with their career stress levels. While the red group has the highest stress level, the green group has been identified to have the lowest stress level. On the other hand, it was achieved that almost half of the students were in the orange group, one level below the red group. Accordingly, it can be argued that the career stress levels of the tourist guide candidates in the red and orange groups are higher than those in other groups. The fact that more than half of the guide candidates are in the red and orange groups shows that the most of the students have career stress. The career stress of the guide candidates in the red group with the highest stress level has been higher than the ones in other groups. The career stress of the guide candidates in the green group has been lower than the ones in other groups in terms of both general and sub-dimensions. Therefore, it can be 
argued that the guide candidates in the red group with high career stress have more external conflict with their family and immediate surroundings. It can be suggested that these candidates feel employment pressure more intensively and that they are more concerned about their insufficient knowledge about the occupation they want. It can also be asserted that these candidates have more career ambiguity as they do not know exactly what kind of qualifications their carrier requires, what is necessary for their career. It can be stated that the guide candidates in the green group who are very relaxed regarding the career stress do not have an intensive stress and pressure in terms of employment pressure, lack of information, career ambiguity and external conflict.

Upon these conclusions, it is seen that most of the guide candidates who do not have sufficient knowledge about the tourism guiding occupation in university years cannot trust their existing knowledge and abilities completely and that they are uncertain about their career goals and have stress due to exposure to employment pressure. Although it is not likely to remove this stress, it can be suggested to include the course of 'career planning' or 'career development' in the curriculum to reduce this stress. It can also be suggested to include the courses which support theoretical knowledge about the tourism guiding occupation with practical applications and sectorial examples, into the curriculum and these courses should be given by specialist academics. In these courses, the stress factors that tourist guide candidates may face in business life can be explained clearly and practically. Students can be provided with consultancy services given by the academics, who are licensed tourist guides, and all other academics in the department of tourism guiding. The guide candidates may be supported so that they become responsible individuals, thus, they undertake their responsibilities and develop themselves properly for the tourist guiding occupation.

\section{References}

Agolla, J. E \& Ongori, H. (2009). An assessment of academic stress among undergraduate students: The case of University of Botswana, Educational Research and Reviews, 4(2), 63-70.

Ahipaşaoğlu, S. (2006). Turizmde rehberlik. (2. Bs.). Gazi Kitabevi.

Ap, J. \& Wong, K. K. F. (2001). Case study on tour guiding: Professionalism, issues and problems. Tourism Management, 22(5), 551-563.

Areekkuzhiyil, S. (2014). Factors influencing the organizational stress among teachers working in higher education sector in Kerala: An empirical analysis. Research and Pedagogic Interventions, 2(2), 1-15. 
Aydın Tükeltürk, Ş. \& Şahin Perçin, N. (2008). Turizm sektöründe kadın çalışanların karşılaştıkları kariyer engelleri ve cam tavan sendromu: Cam tavanı kırmaya yönelik stratejiler. Yönetim Bilimleri Dergisi, 6 (2), 113-128.

Bayat, B. (2014). Uygulamalı sosyal bilim araştırmalarında ölçme, ölçekler ve "likert" ölçek kurma tekniği. Gazi Üniversitesi İktisadi ve İdari Bilimler Fakültesi Dergisi, 16 (3), 1-24.

Bhagat, R. S., Krishnan, B., Nelson, T. A., Leonard, K. M., Ford, D. L. \& Billing, T. K. (2010). Organizational stress, psychological strain and work outcomes in six national contexts: A closer look at the moderating influences of coping styles and decision latitude. Cross Cultural Management: An International Journal,17(1), 10-29.

Black, R. \& Weiler, B. (2005). Quality assurance and regulatory mechanisms in the tour guiding industry: A systematic review. The Journal of Tourism Studies, 16(1), 24-37.

Bozyiğit, E. \& Gökbaraz, N. (2020). Spor bilimleri fakültesi öğrencilerinde kariyer stresinin belirleyicileri. Journal of Computer and Education Research, 8 (15), 181-200.

Bryant, B. K., Zvonkovic, A. M. \& Reynolds, P. (2006). Parenting in relation to child and adolescent vocational development. Journal of Vocational Behavior, 69(1), 149-175.

Can, H., Akgün A. \& Kavuncubaşı, Ş. (1998). Kamu ve özel kesimde insan kaynakları yönetimi. Siyasal Kitabevi.

Cheng, J. C., Chen, C. Y., Teng, H. Y. \& Yen, C. H. (2016). Tour leaders' job crafting and job outcomes: The moderating role of perceived organizational support. Tourism Management Perspectives, 20, 19-29.

Choi, B. Y., Park, H. R., Nam, S. K., Lee, J., Daeyeon, C. \& Lee, S. M. (2011). The development and initial psychometric evaluation of the Korean career stress inventory for college students. Career Development Quarterly, 59(6), 559-572.

Crampton, S. M. \& Mishra, M. (1999). Women in management. Public Personnel Management, 28(1), 87-106.

Çetinkaya, T. (2019). The analysis of academic motivation and career stress relationships of the students in department of physical education and sport. International Education Studies, 12(4), 24-35.

Çınar, B. (2018). Turizm rehberliği bölümü öğrencilerinde genel özyeterlilik algısı, mesleki kayğ ve mesleği yapma niyeti ilişkisi [Yüksek Lisans Tezi], Mersin Üniversitesi. 
Değirmencioğlu, Ö. \& Ahipaşaoğlu, S. (2003). Anadolu'da turizm rehberliği temel bilgileri. Gazi Kitabevi.

Doğan, H. (2014). Çağdaş kariyer karar verme yaklaşım ve modellerinin incelenmesi. Türkiye Sosyal Politika ve Çalışma Hayatı Araştırmaları Dergisi, 4(6), 100-130.

Dumanlı, Ş. \& Köroğlu, Ö. (2018). Turist rehberlerinin stresle başa çıkma tarzları ile mizah tarzları arasındaki ilişkinin belirlenmesi. Journal of Yasar University, 13(52), 328-342.

Eren Gümüştekin, G. \& Gültekin, F. (2009). Stres kaynaklarının kariyer yönetimine etkileri. Dumlupınar Üniversitesi, Sosyal Bilimler Dergisi, 23, 147-158.

Fouad, N. A., Guillen, A., Harris-Hodge, E., Henry, C., Alexandra, N., Terry, S., et al. (2006). Need, awareness, and use of career services for college students. Journal of Career Assessment. 14, 407-420.

Gbadamosi, G. \& Ross, C. (2012). Perceived stress and performance appraisal discomfort: The moderating effects of core self-evaluations and gender. Public Personnel Management, 41(4), 637-659.

Greenberg, J. \& Baron, R. A. (1995). Behavior in organizations: Understanding and managing the human side of work, Prentice-Hall International.

Güzel, F.Ö. (2007). Türkiye imajının geliştirilmesinde profesyonel turist rehberlerinin rolü (Alman turistler üzerine bir araştırma) [Yüksek Lisans Tezi], Balıkesir Üniversitesi.

Güzel, F. \& Köroğlu, Ö. (2015). Turist rehberlerinin mesleklerine yönelik pozitif ve negatif yönlü algılarının içerik analizi yöntemi ile belirlenmesi. Cumhuriyet Üniversitesi İktisadi ve İdari Bilimler Dergisi, 16 (1), 155-174.

Hacıoğlu, N. (2008). Türkiye'de Profesyonel Turist Rehberliği Eğitimine Yeni Bir Yaklaşım, III. Balıkesir Ulusal Turizm Kongresi: 17-19 Nisan 2008, Bildiri Kitabı (244-247). Nobel Yayın Dağıtım.

Işık, E. (2010). Sosyal bilişsel kariyer teorisi temelli bir grup müdahalesinin üniversite öğrencilerinin kariyer kararı yetkinlik ve mesleki sonuç beklenti düzeylerine etkisi [Doktora Tezi], Çukurova Üniversitesi.

Jang, H. S. (2000). The sources of stress of university students and their coping strategies. Journal of Student Guidance Research, 32, 101-115.

Kaplanoğlu, E. (2014). Mesleki stresin temel nedenleri ve muhtemel sonuçları: Manisa İli'ndeki SMMM'ler üzerine bir araştırma. Muhasebe ve Finansman Dergisi.

Kardaş, K. (2020). Turizm rehberliği bölümleri için araştırma ve müfredat kapsam önerisi [Yüksek Lisans Tezi], Mersin Üniversitesi. 
Keller, B. K. \& Whiston, S. C. (2008). The role of parental influences on young adolescents' career development. Journal of Career Assessment 16(2), 198217.

Kim, S. K. (2003). Life stress in freshmen and adjustment to college. Korean Jounal of Youth Studies, 10, 215-237.

Köroğlu, Ö. (2013). Turist rehberlerinin iş yaşamındaki rolleri üzerine kavramsal bir değerlendirme. Pamukkale Üniversitesi Sosyal Bilimler Enstitüsü Dergisi, 16, 91-112.

Lazarus, R. S. (1993). From psychological stress to the emotions: A history of changing outlooks. Annual Review of Psychology, 44, 1-21.

Lease, S. H. (2004). Effect of locus of control, work knowledge, and mentoring on career decision-making difficulties: Testing the role of race and academic institution. Journal of Career Assessment, 12, 239-254.

Mavisu, H. (2010). Bireysel kariyer planlamanın aşamalarından biri olarak hedef belirleme ve kariyer başarısı ilişkisi [Yüksek Lisans Tezi], Dokuz Eylül Üniversitesi.

Örücü, E., Kılıç, R. \& Kılıç, T. (2007). Cam tavan sendromu ve kadınların üst düzey yönetici pozisyonuna yükselmelerindeki engeller: Balıkesir İli örneği. Yönetim ve Ekonomi, 14(2), 117-135.

Özdel, C. B. (2009). Meslek lisesiöğrencilerinin mesleki yönelimlerine etkieden faktörler: Küçükçekmece İlçesi örneği [Yüksek Lisans Tezi], Beykent Üniversitesi.

Özden, K. \& Sertel Berk, Ö. (2017). Kariyer stresi ölçeğinin (KSÖ) Türkçe'ye uyarlanması ve sikometrik özelliklerinin sınanması. Psikoloji Çalışmaları Dergisi, 37-1, 35-51.

Özmutaf, N. M. (2006). Örgütlerde insan kaynakları ve stres: Ampirik bir yaklaşım. Ege Üniversitesi Su Ürünleri Dergisi, 23 (1-2), 75-81.

Pond, K. (1993). The professional quide: Dynamics of tour guiding. New York: Van Nostrand Reinhold.

Profesyonel Turist Rehberliği Yönetmeliği (R.G. Tarihi: 25.11.2005 R.G. Sayısı: 26004). On 31 October 2020 https://teftis.ktb.gov.tr/TR-14521/profesyonelturist-rehberligi-yonetmeligi-rg-tarihi-251-.html accessed from.

Robbins, S. P. (2001). Organizational behavior. New Jersey: Prentice-Hall, Inc.

Rottinghaus, P. J., Jenkins, N. \& Jantzer, A. M. (2009). Relation of depression and affectivity to career decision status and self-efficacy in college students. Journal of Career Assessment, 17, 271-285.

Sabuncuoğlu, Z. (2005). İnsan kaynakları yönetimi. Alfa Yayınları.

Sav, D. (2008). Bireysel kariyer planlamada etkili olan faktörler ve üniversitelerin etkisi üzerine bir araştırma [Yüksek Lisans Tezi], Süleyman Demirel Üniversitesi. 
Şeker, G. \& Kaya, A. (2018). Lise öğrencilerinin meslek seçiminde aile desteği: Bir ölçek geliştirme çalışması. Türk Psikolojik Danışma ve Rehberlik Dergisi, 8(49), 157-171.

Temizkan, S. P. (2010). Profesyonel turist rehberlerinin turizm pazarlamasindaki rolüne etkisi açısından hizmet içi eğitim seminerleri [Doktora Tezi], Gazi Üniversitesi.

Tolga. Ö., Korkmaz, H. \& Atay, L. (2015). Lisans düzeyindeki turist rehberliği öğrencilerinin mesleki tutumlarına yönelik bir araştırma. Seyahat ve Otel İsletmeciliği Dergisi, 12(2), 26-41.

Turner, S. \& Lapan, R. T. (2002). Career self-efficacy and perceptions of parent support in adolescent career development. The Career Development Quarterly, 51(1), 44-55.

Turpcu, E. \& Akyurt H. (2018). Turizm eğitimi alan öğrencilerin kariyer streslerinin belirlenmesi: Giresun Üniversitesi lisans öğrencileri üzerine bir araştırma. International Journal of Social Science, 69, 365-380.

Türk Dil Kurumu. Türk Dil Kurumu sözlükleri. On 03 October 2020 https:// sozluk.gov.tr/ accessed from.

Ural, A. \& Kılıç, İ. (2005). Bilimsel araştırma süreci ve SPSS ile veri analizi. Detay Yayincilik.

Weiler, B. \& Black, R. (2015), Tour guiding research: Insights, issues and implications. Channel View Publications.

Weng, Y. F., Chiang, M. H. \& Lee, Y. J. (2014). The relationships amongst the intern anxiety, internship outcomes and career commitment of hospitality college students. Journal of Hospitality, Leisure, Sport and Tourism Education, 15, 86-93.

World Federation of Tourist Guide Associations. What is a tourist guide? On 05 October $2020 \mathrm{http} / /$ www.wftga.org/tourist-guiding/what-touristguide accessed from.

Yılmaz, A. (2019). Öğretmen adaylarının kariyer stresinin karma araştırma yaklaşımı ile incelenmesi. Türk Spor Bilimleri Dergisi, 2(1), 93-105.

Yükseköğretim Program Atlası. Yök önlisans atlası. On 25 October 2019 https:// yokatlas.yok.gov.tr/ accessed from.

\section{Ethical approval}

This study is among the studies that do not require ethics committee approval due to fact that the survey was conducted in April, May 2019.

\section{Conflict of interest}

There is no potential conflict of interest in this study. 